\title{
Communication
}

[Comunicação]

\section{High genetic diversity of hepatitis E virus in swine in São Paulo State, Brazil}

[Diversidade genética do vírus da hepatite E em suínos no estado de São Paulo, Brasil]

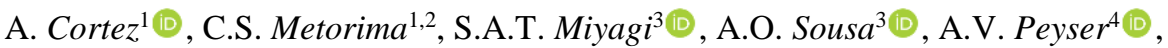 \\ A.M.M.G. Castro $^{5}$ (D) F.A. Baldisseri Jr ${ }^{1}$ (D) A.F. Souza Filho ${ }^{3}$ (D), \\ P.E. Brandão ${ }^{3}$ (D) M.B. Heinemann ${ }^{3 *}$ (D)
}

\author{
${ }^{1}$ Universidade Santo Amaro, UNISA, São Paulo, SP, Brasil \\ ${ }^{2}$ Undergraduate, Universidade Santo Amaro, UNISA, São Paulo, SP, Brasil \\ ${ }^{3}$ Universidade de São Paulo, USP, Faculdade de Medicina Veterinária e Zootecnia, São Paulo, SP, Brasil \\ ${ }^{4}$ Graduate, Universidade Santo Amaro, UNISA, São Paulo, SP, Brasil \\ ${ }^{5}$ Faculdade Alvorada - São Paulo, SP, Brasil
}

Hepatitis E virus (HEV), a member of the Orthohepevirus A species, can infect mammals and humans and may be classified into genotypes and subtypes (Smith et al., 2020). In South America, genotype 1 (HEV-1) is restricted to humans, and transmission occurs via the fecaloral route. Zoonotic genotype 3 (HEV-3) is related to humans, pigs, wild boar, sewage, rivers, drinking water plants, and slaughterhouse effluent (Pisano et al., 2018).

Both serological and molecular detection of HEV-3 infection in domestic pigs have been demonstrated in several Brazilian regions and South America, and the subtypes are $3 \mathrm{a}-\mathrm{f}$ and $\mathrm{h}$ (Campos et al., 2018; Pisano et al., 2018; Silva et al., 2018; Oliveira-Filho et al., 2019), but there are only two records of HEV-3 in pigs in São Paulo state (Paiva et al., 2007; Bertolini, 2017).

Therefore, due to scarce information concerning this viral infection, the aim of this work was to assess the occurrence of HEV in samples from a biological bank of swine feces from the state of São Paulo.

Fecal samples from 89 swine collected between 2008 and 2009 from the metropolitan region of Campinas were analyzed using nested reverse transcriptase-polymerase chain reaction (RTnPCR) and Sanger sequencing. This study was carried out following the recommendations in the
Brazilian National Guidelines on Animal Experimentation. The protocol was approved by the Universidade Santo Amaro Ethics Committee on Animal Use (32/2013).

RNA extraction was conducted using a $10 \%$ aqueous diethyl pyrocarbonate (DEPC) fecal suspension and TRIzol Reagent (Ambion ${ }^{\mathrm{TM}}$ Carlsbad, USA) according to the manufacturer's instructions. Complementary DNA (cDNA) was synthesized using random primers (Invitrogen ${ }^{\mathrm{TM}}$, Carlsbad, USA) and MML-V Reverse Transcriptase (Invitrogen ${ }^{\mathrm{TM}}$, Carlsbad, USA) following the manufacturer's instructions.

ORF-1 nested PCR (Wang et al., 1999) amplification was carried out with the primers Cons-ORF1-s1 and ConsORF1-a1 (external) and ConsORF1-s2 and ConsORF1-a2. The first amplification was carried out in a final volume of $20 \mu \mathrm{L}$ using $2.0 \mu \mathrm{L}$ of cDNA, 8 pmol of each primer, 1x Promega GoTaq® Green Master Mix, and DEPC water q.s.p.. The second amplification was performed using $1 \mu \mathrm{L}$ of the amplicon and the same reagents and concentrations. Both PCRs were carried out under identical conditions: (1) initial denaturation at $94^{\circ} \mathrm{C}$ for 4 min; (2) 40 cycles of amplification $\left(94^{\circ} \mathrm{C} / 15 \mathrm{~s}\right.$ denaturation, $50^{\circ} \mathrm{C} / 15 \mathrm{~s}$ annealing, and $72{ }^{\circ} \mathrm{C} / 45$ s extension); and (3) a final extension at $72{ }^{\circ} \mathrm{C}$ for 5 min. Nested ORF-2 PCR (Huang et al., 2002) included the primers $3156 \mathrm{NF}$ and $3157 \mathrm{NR}$ (external) and $3158 \mathrm{NF}$ and $3159 \mathrm{NR}$ (internal).

*Corresponding author: marcosbryan@usp.br

Submitted: October 3, 2020. Accepted: May 24, 2021. 
The first amplification was carried out in a final volume of $25 \mu \mathrm{L}$, comprising $2.5 \mu \mathrm{L}$ of cDNA $1 \mathrm{X}$ Promega Go Taq ${ }^{\circledR}$ Green Master Mix (Promega, Madison, USA), 10 pmol of each primer and DEPC water q.s.p. Conditions for the first amplification were initial denaturation at $94^{\circ} \mathrm{C}$ for $4 \mathrm{~min}$, followed by 40 cycles $\left(94^{\circ} \mathrm{C} / 15 \mathrm{~s}\right.$ denaturation, $52^{\circ} \mathrm{C} / 30 \mathrm{~s}$ annealing, and $72^{\circ} \mathrm{C} / 1$ min extension) and a final extension at $72^{\circ} \mathrm{C}$ for $5 \mathrm{~min}$. The second amplification was performed using $1 \mu \mathrm{L}$ of the amplicon and the same reagents, concentrations, and amplification conditions from the first amplification, except for the extension time $\left(72{ }^{\circ} \mathrm{C} / 30 \mathrm{~s}\right)$. The ORF-1 (287 bp) and ORF-2 (348 bp) fragments were run on a $1.5 \%$ agarose gel, stained with SYBR Safe ${ }^{\circledR}$ (Thermo Fisher Scientific, Carlsbad, USA), and visualized under UV light.

PCR products were purified with a QIAquick PCR purification kit (Qiagen Inc. Valencia, CA), and nucleotide sequencing of PCR products was performed in an ABI 3500 (Applied Biosystems $^{\circledR}$, Carlsbad, USA) automatic sequencer using BigDye 3.1 (Applied Biosystems ${ }^{\circledR}$, Carlsbad, USA). Electropherogram quality analysis and consensus sequence analysis were performed using Phred and CAP3 software (http://asparagin.cenargen.embrapa.br/phph/2.

Similarity searches were conducted using BLASTn

lm.nih.gov/BLAST/).

The resulting sequences were genotyped by phylogenetic reconstruction using reference sequences (Silva et al., 2018; Smith et al., 2020) and GenBank sequences. GenBank accession numbers, genotypes, and countries of origin are related in the phylogenetic tree. Phylogenetic trees were generated by the neighbor-joining method with the Kimura 2-parameter method (ORF-1) or the maximum composite likelihood method (ORF-2) for evolutionary distances, complete deletion and 1,000 bootstrap replicates with Mega 7.0.21 (Kumar et al., 2016). Avian HEV was used as an outgroup. The sequence identity matrix was generated with BioEdit software version 7.0.8.0 (http://www.mbio.ncsu.edu/bioedit/bioedit.html).

Seven out of 89 stool samples were positive for the ORF-1 region, three collected in 2008 and four in 2009. Of the seven, three showed positive amplification for ORF-2, which suggests differences in sensitivity between protocols or gene diversity (Silva et al., 2018). A possible explanation is that there are differences in the anchoring of the primers due to possible mutations in the Brazilian sequences, which is reflected in the lower proportion of detection.

Phylogenetic analysis of both partial ORF-1 and ORF-2 sequences (fig. 1 and 2) showed that all seven samples belonged to HEV-3 zoonotic genotypes (Pisano et al., 2018; Oliveira-Filho et al., 2019). The finding of HEV-3 in the metropolitan region of Campinas increased the viral dispersion previously described in the southeastern region (Paiva et al., 2007; Bertolini 2017) and may explain the presence of HEV seropositivity in human populations in 2000 (Gonçales et al., 2000). The sequences were deposited in GenBank under accession numbers MF981263-MF981272.

Figure 1 shows the genetic diversity of HEV samples from the state of São Paulo. The presence of subgenotypes 3b (MF981263, MF981264, and MF981265), 3h (MF981266 and MF981267), and 3j (MF981268) can be observed by phylogenetic partial ORF-1 analysis.

The sequences MF981266 and MF981267 obtained in this study clustered with Brazilian sequences (KU888662-KU888663) from pork bioproducts at Rio Grande do Sul (Heldt et al., 2016), with $98.3 \%$ to $98.9 \%$ nucleotide identity, and clustered with subtype HEV-3h, showing $87 \%$ nucleotide identity with the reference subtype JQ013794 (Smith et al., 2020) from humans. This clade forms a sister group with swine isolates from Rio Grande do Sul that have similarities with human samples from Uruguay. This subtype was first reported in backyard pigs in Rio Grande do Sul (Silva et al., 2018). It is noteworthy that both MF981266 and MF981267 were identified in 2008, suggesting the presence of this genotype for at least one decade in the state of São Paulo.

The sequence MF981268 clustered with 90.8\% similarity with the Arkell HEV strain swine HEV-3j. The subtype HEV-3j has not previously been in Brazil/South America (Pisano et al., 2018). 
High genetic diversity...

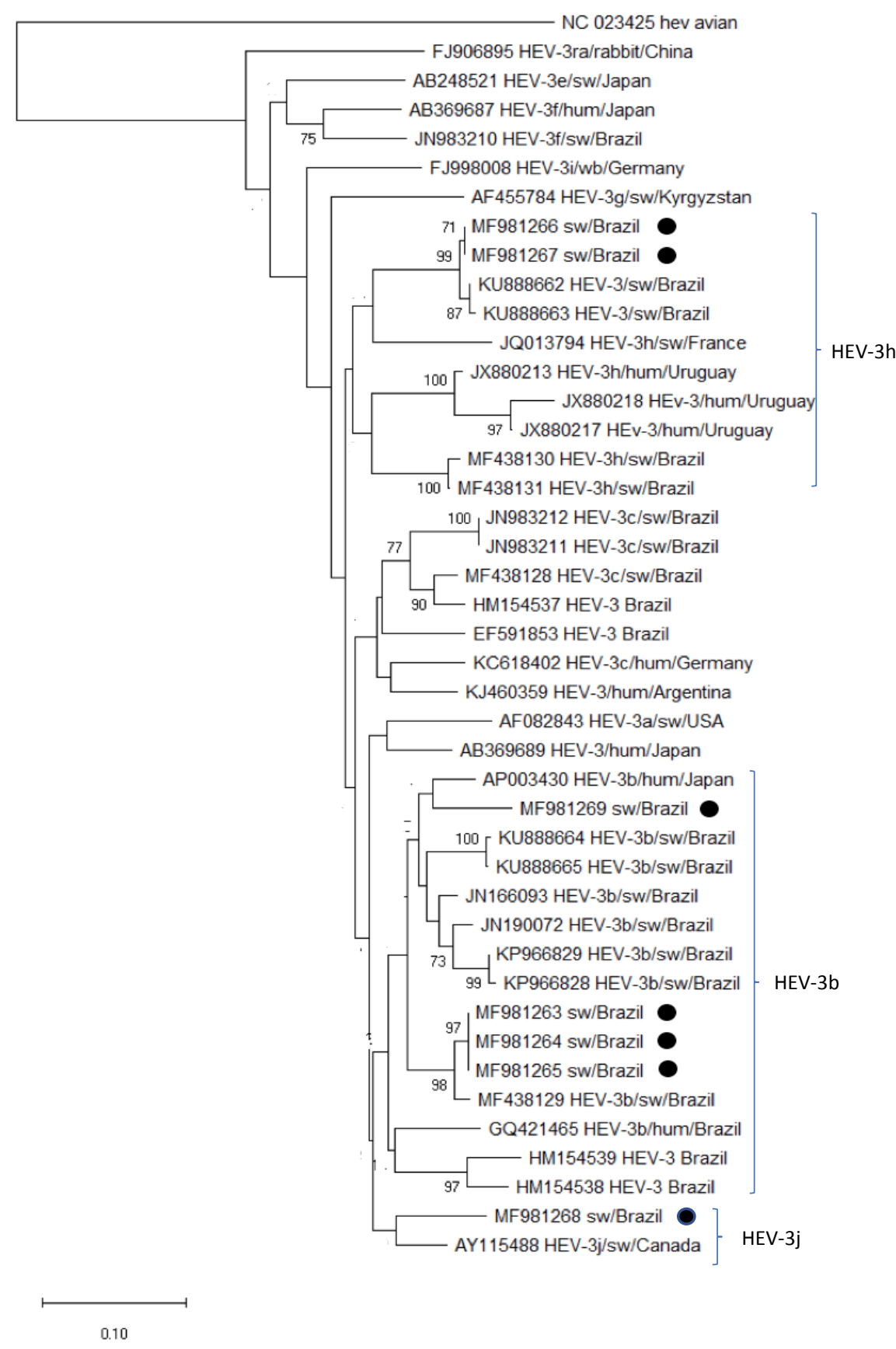

Figure 1. The tree was inferred using the Neighbor-Joining method using the Maximum Composite Likelihood parameter model. It was constructed from 260 nucleotide sequences of a partial ORF- 1 . The analysis involved 43 nucleotide sequences. Phylogenetic analyses were conducted in MEGA 7.0.21 with 1,000 bootstrap replicates. Bootstrap values of $>70$ were shown. Avian HEV was used as an outgroup. The sequences from this study are indicated by a black dot.

The sequence MF981269 clustered with the reference isolate JRA1 (AP003430) for subtype 3b, with $91.9 \%$ nucleotide similarity. The MF981263-MF129865 sequences clustered with the swHEVBR_108-02 isolate (HEV-3b) identified from the swine serum of Rio Grande do Sul (MF438129), with a nucleotide identity of $97.8 \%$. This classification obtained by the 
analysis of ORF-1 was supported by the analysis of ORF-2 (MF981270-MF981272) (Fig. 2). These sequences formed a sister group with Brazilian sequences obtained from human patients. The genetic analysis corroborates the study in Rio Grande do Sul (Silva et al., 2018) and reinforces the zoonotic potential of HEV-3b.
The other single sequence (EF491206) from São Paulo (Paiva et al., 2007) clustered with newly described subtype HEV-3i (FJ998008) reference sequences (Smith et al., 2020), which have not been previously described in Brazil.

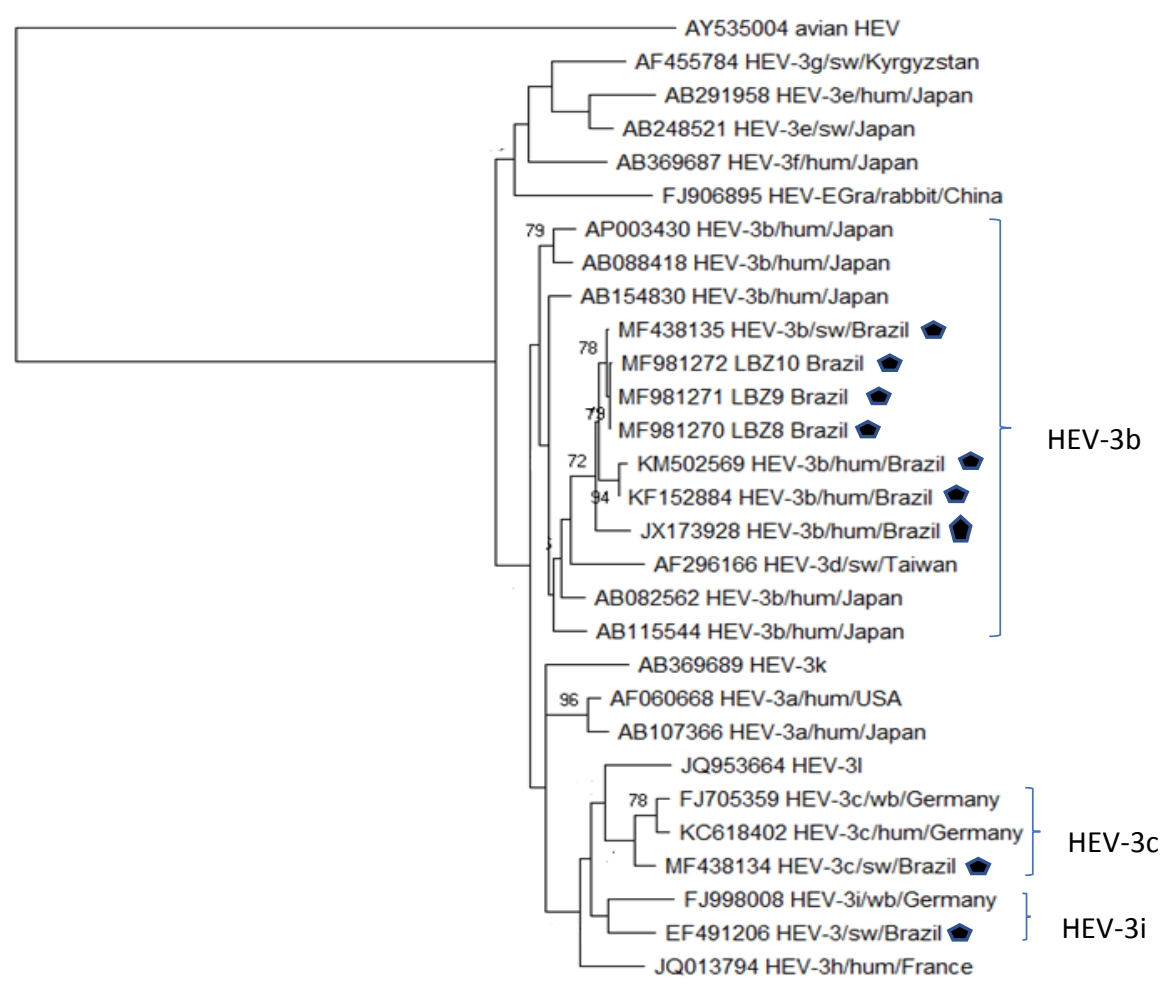

0.20

Figure 2. The tree was inferred using the Neighbor-Joining method using the Maximum Composite Likelihood parameter model. It was constructed from 260 nucleotide sequences of a partial ORF- 2. The analysis involved 27 nucleotide sequences. Phylogenetic analyses were conducted in MEGA 7.0.21 with 1,000 bootstrap replicates. Bootstrap values of $>70$ was shown. Avian HEV was used as an outgroup. The sequences from this study are indicated by a black form.

Considering the genotypic variety found in São Paulo state in samples collected in the late 2000s, molecular epidemiology studies are necessary in humans and animals to understand the dispersion of these genotypes and the current seropositivity found in humans. The present data demonstrated the presence of HEV subtypes not previously described in Brazil, indicated elevated genetic diversity in the state of São Paulo and reinforced the zoonotic potential of $\mathrm{HEV}-3$.

Keywords: Brazil, domestic pig, food, hepatitis E virus, molecular characterization 
High genetic diversity...

\section{RESUMO}

A hepatite E é uma zoonose emergente que afeta diversas espécies de mamíferos, inclusive o ser humano. É ocasionada por um vírus da espécie Orthohepevirus A que possui diversos genótipos e subgenótipos. No Brasil é descrito o genótipo HEV-3, cujo principal reservatório é o porco doméstico. Testes moleculares e sorológicos demonstram o HEV-3 em diferentes estados, tanto em animais quanto em humanos. No estado de São Paulo, existem diversos estudos sobre a epidemiologia da hepatite E em humanos, mas faltam informações sobre o HEV-3 em suinos. Assim, o objetivo deste trabalho foi verificar a ocorrência de HEV por meio da técnica de RT-PCR e posterior sequenciamento em um banco de amostras de fezes de suínos colhidas entre 2008 e 2009, na região metropolitana de Campinas. Das 89 amostras analisadas, foi possível detectar o HEV-3 em sete e, pela reconstrução filogenética, foram encontrados os subgenótipos HEV-3b, HEV-3h, e HEV-3j. Uma amostra disponível no GenBank, proveniente de São Paulo, que ainda não havia sido subgenotipada, foi agrupada ao HEV-3i. Os subgenótipos HEV-3j e HEV-3i ainda não tinham sido relatados no país. O estudo demonstra uma grande diversidade genética do HEV no estado de São Paulo e reforça o caráter zoonótico da HEV-3.

Palavras-chave: hepatite E, suíno, caracterização molecular, Brasil

\section{CONTRIBUTION}

$\mathrm{AC}$ and $\mathrm{MBH}$ were responsible for supervision. $\mathrm{AC}, \mathrm{PEB}, \mathrm{MBH}$ were responsible for the planning of the experiments, interpretation and discussion of the data and drafted the manuscript. AC, AMVP, CSM, SATM, AOS were responsible for the execution of the experiments and interpretation of the data. AMMGC and FAB were responsible for discussion of the data and manuscript draf. All authors reviewed the results and approved the final version of the manuscript.

\section{ACKNOWLEDGEMENTS}

We thank the researchers Marcelo Alves Pinto, Sheila Oliveira de Souza and Jane Megid for their collaboration in this study. $\mathrm{MBH}$ (309145/2017-8) and PEB thank CNPq (National Council for Scientific and Technological Development) for the research productivity fellowships (PQ). RMB thank CNPq for PIBIC fellowship.

\section{FUNDING}

This work was supported by the National Council for Scientific and Technological Development (Conselho Nacional de Desenvolvimento Científico e Tecnológico, CNPq) and Coordination of Superior Level Staff Improvement (Coordenação de Aperfeiçoamento de Pessoal de Nível Superior, CAPES), Financial Code 001.

\section{DATA AVAILABILITY STATEMENT}

The data that support the findings of this study are openly available in GenBank at https://www.ncbi.nlm.nih.gov/genbank/, reference number MF981263-MF981272.

\section{REFERENCES}

BERTOLINI PM. Detecção do vírus da hepatite E em fezes de suínos abatidos sob inspeção sanitária. 2017. 81f. Dissertação (Mestrado em Medicina Veterinária) - Universidade Estadual Paulista "Júlio de Mesquita Filho", Faculdade de Medicina Veterinária e Zootecnia, São Paulo, SP.

CAMPOS, C.G.; SILVEIRA, S.; SCHENKEL, D.M. et al. Detection of hepatitis E virus genotype 3 in pigs from subsistence farms in the state of Mato Grosso, Brazil. Comp. Immunol. Microbiol. Infect. Dis., v.58, p.11-16, 2018.

GONÇALES, N.S.; PINHO, J.J.R.; MOREIRA R.C. et al. Hepatitis E virus immunoglobulin G antibodies in different populations in Campinas, Brazil. Clin. Diagn. Lab. Immunol., v.7, p.813$816,2000$.

HELDT, F.H.; STAGGMEIER, R.; GULARTE, J.S. et al. Hepatitis E virus in surface water, sediments, and pork products marketed in Southern Brazil. Food Environ. Virol., v.8, p.200-205, 2016. 
HUANG, F.F.; HAQSHENAS, G.; GUENETTE, D.K. et al. Detection by reverse transcriptionPCR and genetic characterization of field isolates of swine hepatitis E virus from pigs in different geographic regions of the United States. J. Clin. Microbiol., v.40, p.1326-1332, 2002.

KUMAR, S.; STECHER, G.; TAMURA K. MEGA7: molecular evolutionary genetics analysis. Version 7.0 for Bigger Datasets. Mol. Biol. Evol., v.33, p.1870-1874, 2016.

OLIVEIRA-FILHO, E.F.; SANTOS， D.R.; DURÃES-CARVALHO, R. et al. Evolutionary study of potentially zoonotic hepatitis E virus genotype 3 from swine in Northeast Brazil. Mem. Instit. Oswaldo Cruz, v.114, p.e180585, 2019.

PAIVA, H.H.; TZANEVA, V.; HADDAD, R.; YOKOSAWA, J. Molecular characterization of swine hepatitis E virus from Southeastern Brazil. Braz. J. Microbiol., v.38, p.693-698, 2007.
PISANO, M.B.; MARTINEZ-WASSAF, M.G.; MIRAZO S. et al. Hepatitis E virus in South America: the current scenario. Liv. Int., v.38, p.1536-1546, 2018.

SILVA, M.S.; SILVEIRA, S.; CARON, V.S. et al. Backyard pigs are a reservoir of zoonotic hepatitis E virus in southern Brazil. Trans. Rev. Soc. Trop. Med. Hyg., v.112, p.14-21, 2018.

SMITH, D.B.; IZOPET, J.; SIMMONDS, P. et al. Update: proposed reference sequences for subtypes of hepatites $\mathrm{E}$ virus (species Orthohepevirus A). J. Gen. Virol., v.10, p.692$698,2020$.

WANG, Y.; LING, R.; ERKER, J.C. A divergent genotype of hepatitis $\mathrm{E}$ virus in Chinese patients with acute hepatitis, J. Gen. Virol., v.80, p169177, 1999. 